\title{
Antifungal compounds as a mechanism to control Hemileia vastatrix by antagonistic bacteria
}

\author{
Fernando Haddad ${ }^{a}$, Rodrigo M. Saraiva, Eduardo S. G. Mizubuti, Reginaldo S. Romeiro ${ }^{\text {\& }}$ Luiz A. \\ Maffia
}

Departamento de Fitopatologia, Universidade Federal de Viçosa, 36570-000, Viçosa, MG, Brazil

Author for correspondence: Luiz A. Maffia, e-mail: lamaffia@ufv.br

\begin{abstract}
Pseudomonas putida P286 and Bacillus thuringiensis B157 controlled coffee rust under greenhouse and field conditions. Now we studied the mechanism(s) of antagonism of both bacteria to Hemileia vastatrix. Bacterial effects on urediniospore germination and disease severity were evaluated in experiments with six treatments: (i) growth broth, (ii) supernatant centrifugation, (iii) bacterial cell centrifugation and re-suspension, (iv) UV inactivation of the bacteria, (v) 523 medium, and (vi) saline solution. The treatments i to iii reduced both spore germination and disease severity. Each isolate was applied at different concentrations and time periods before inoculation of $H$. vastatrix. The efficiency in controlling rust was reduced at the lowest concentrations and at the largest intervals between applications. In spatial separation experiments, both bacteria did not induce systemic protection, whereas protected locally the coffee plants against $H$. vastatrix. Therefore, the mechanism of both isolates against $H$. vastatrix is attributed to the production of antifungal compound (s).
\end{abstract}

Key words: Bacillus thuringiensis, Coffea arabica, Pseudomonas putida, biocontrol, coffee, rust

\section{INTRODUCTION}

Brazil is the largest coffee producer and exporter worldwide (MAPA, 2013). There is an increasing demand for "specialty coffees", including those that are produced organically. Organic coffees have additional value, and their production contributes to the reduction of the environmental damage caused by pesticide use (Caixeta, 2002). The most important coffee disease in Brazil is leaf rust, caused by Hemileia vastatrix Berk. \& Br, which can reduce coffee yield by $60 \%$ (Gouveia et al., 2005). Similar to many rusts, disease epidemics in the field are caused by the uredinial phase of the pathogen.

In organic coffee cropping systems, rust can be managed using resistant cultivars and copper-based products (Carvalho et al., 2002). However, it is difficult to achieve durable resistance because of the variability of H. vastatrix (Van der Vossen, 2005). In addition, in Brazil, there is a number of restrictions to the use of copperbased products, whereas the number of organic coffee crop systems is increasing (Carvalho et al., 2002). In these crop systems, biological control is a viable alternative for disease management (Harman, 2000). Using this approach, we have investigated the biocontrol of coffee rust and demonstrated that Pseudomonas putida P286 and Bacillus

aPresent address: Embrapa Mandioca e Fruticultura, 44380-000, Cruz das Almas, BA, Brazil

'In memorian thuringiensis B157 control leaf rust in coffee plants under both greenhouse and field conditions (Haddad et al., 2004; Haddad et al., 2009).

Bacillus and Pseudomonas species are known biocontrol agents of plant diseases (Han et al., 2006; Melnick et al., 2008; Weller et al., 2012). The mechanisms most frequently associated with the antagonistic effect of these species are the production of compounds with antimicrobial activity (De La Fuente et al., 2006; Ryan et al., 2008; Weller et al., 2012) and induced systemic resistance (ISR) (Saravanan et al., 2004; Romeiro et al., 2005; Ongena et al., 2007). Bacillus isolates produce a wide variety of antifungal metabolites, mainly lipopeptides, such as surfactin, itaurine, and fengicine (Lanna Filho et al., 2010).

In Pseudomonas spp., the antibiotic 2,4diacetylphloroglucinol is responsible for natural suppression in the soil (Raaijmakers et al., 1999; Weller et al., 2012). Other compounds produced by Pseudomonas spp., such as pyoluteorin (Duffy \& Défago, 1999) and pyrrolnitrin (Cui \& Harling, 2006; Upadhyay \& Srivastava, 2009), are also important for plant disease control. Other Pseudomonas species were reported to induce resistance against $H$. vastatrix in coffee plants (Porras et al., 1999). The protective effect and the induction of resistance in coffee seedlings were demonstrated when $P$. putida was applied 4 hours before inoculation with $H$. vastatrix or when $B$. subtilis was applied 8 days before inoculation with $H$. vastatrix (Costa, 2007). The germination of $H$. vastatrix was reduced by the application of a B. thuringiensis-based commercial product, and the protective effect of this application to 
coffee-leaf discs inoculated with the pathogen lasted up to 16 days (Cristancho, 1995). Although the results were not conclusive, it was suggested that the application of the product induced a resistance to rust.

In coffee plants, the application of $B$. thuringiensis B157 and P. putida $\mathrm{P} 286$ was shown to control rust efficiently (Haddad et al., 2004; Haddad et al., 2009). To define disease management strategies using these isolates, it is necessary to understand their mechanisms of action against $H$. vastatrix. Therefore, we examined these mechanisms and evaluated the criteria proposed by Steiner \& Schömbeck (1995) to determine whether ISR is related to the effects of the isolates.

\section{MATERIAL \& METHODS}

\section{General procedures}

To define the antagonistic mechanism(s) of $B$. thuringiensis $\mathrm{B} 157$ and P. putida $\mathrm{P} 286$, the following criteria were evaluated: (i) the lack of toxic effects of the inducing agent on the pathogen; (ii) the lack of a relationship between the resistance magnitude and the application of increasing quantities of the inducer; (iii) the need for a time interval between the exposure of the plant to the inducing agent and the resistance expression; and (iv) the resistance response pattern, whether local or systemic (Steiner \& Schömbeck, 1995).

The urediniospores were brush-collected from pustules of leaves of 'Catuaí' plants grown in greenhouse, sieved and suspended in sterilized distilled water (SDW) at a concentration of $1 \mathrm{mg}$ urediniospores $/ \mathrm{mL}$. The suspension was shaken for $40 \mathrm{~min}$ in a magnetic stirrer. The collectionagitation procedures were executed immediately before inoculation with $H$. vastatrix.

The bacterial isolates were stored in potato-dextroseagar (PDA) in culture tubes at $5^{\circ} \mathrm{C}$. Before application, each isolate was grown in 523 liquid medium (Kado \& Heskett, 1970) in Erlenmeyer flasks that were shaken in an orbital agitator for $24 \mathrm{~h}$ at $150 \mathrm{rpm}$ and $30^{\circ} \mathrm{C}$.

\section{Urediniospore germination in presence of bacterial cells and possible cell-produced metabolites}

For each bacterial isolate, the following four treatments were performed: (i) culture broth collected after bacterial growth in 523 liquid medium; (ii) supernatant collected by centrifugation of the culture broth at 14.000 rpm for $20 \mathrm{~min}$; (iii) bacterial cells collected (after the centrifugation treatment described in ii) and resuspended in $0.85 \% \mathrm{NaCl}$ saline solution; and (iv) cells collected from treatment iii and inactivated by exposure to ultraviolet radiation for $30 \mathrm{~min}$. The following three control treatments were included: $\mathrm{C} 1,10 \mu \mathrm{L}$ saline solution $+10 \mu \mathrm{L}$ urediniospore suspension; $\mathrm{C} 2,10 \mu \mathrm{L}$ copper hydroxide $(2.2$ g i.a./L) $+10 \mu \mathrm{L}$ urediniospore suspension; and $\mathrm{C} 3,10 \mu \mathrm{L}$ 523 medium $+10 \mu \mathrm{L}$ urediniospore suspension.

A $10 \mu \mathrm{L}$ sample of each treatment $+10 \mu \mathrm{L}$ of the urediniospore suspension were placed in Petri dishes (5-cm diameter) containing $1.5 \%$ agar-water. The Petri dishes were maintained at $22^{\circ} \mathrm{C}$ in the dark. After $16 \mathrm{~h}$, $5 \mu \mathrm{L}$ of lactophenol was added to each dish to terminate the urediniospore germination. The germination of 100 urediniospores was assessed using light microscopy. A spore was considered germinated when the length of the germination tube was equal to or larger than the spore length. The ability of each treatment to reduce the germination efficiency compared to the corresponding control treatment was evaluated. Treatments iii and iv were compared to $\mathrm{C} 1$, while treatments (i) and (ii) were compared to $\mathrm{C} 3$.

Each experiment was performed twice using a completely randomized design with three replications (one Petri dish $=$ one experimental unit).

\section{Rust severity in presence of bacterial cells and possible antagonist-produced metabolites}

The treatments described in the previous section were applied by spraying, up to the running point, the abaxial face of the second and third pair of leaves from the apex of six-month-old 'Catuaí' plants that were grown in plastic bags in the greenhouse. The plants were maintained in a dew chamber (relative humidity $>90 \%$ ) at $25^{\circ} \mathrm{C}$ in the dark. After $48 \mathrm{~h}$, the $H$. vastatrix was inoculated at the treatment site, and the plants were transferred back to the dew chamber. 48 hours after inoculation (hai), the plants were transferred to the greenhouse. After 40 days, the inoculated leaves were collected and photographed, and their images were scanned and analyzed to estimate the rust severity using the Quant software (Vale et al., 2003). The efficiency of each treatment at reducing rust severity was calculated relatively to the corresponding control treatment as described above.

The experiment was performed twice using a completely randomized design with three replications (one plant $=$ one experimental unit).

\section{Urediniospore germination in coffee plants seedlings in presence of antagonistic bacteria}

Cell suspensions of each bacterial isolate, grown in 523 medium, were prepared in $0.85 \% \mathrm{NaCl}$ saline solution $+0.05 \%$ Tween 20 , and the concentration was adjusted to $\mathrm{OD}_{540}=0.2$ using a spectrophotometer. The 523 medium + $0.85 \% \mathrm{NaCl}$ saline solution $+0.05 \%$ Tween 20 was used as control treatment. Each treatment was applied to the abaxial face of the second pair of leaves, followed by an immediate inoculation with $H$. vastatrix at the same site. The plants were maintained in a dew chamber at $25^{\circ} \mathrm{C}$ in the dark.

After $0,3,6,12,18$, and $24 \mathrm{~h}$, the spore germination was evaluated under light microscopy on glass slides prepared in accordance with Silva et al. (1999). The application/ inoculation sites were covered using colorless enamel. After drying, enamel was removed, and a foil-formed film was set on a slide using a drop of blue lactophenol. Six microscope fields, each containing 100 urediniospores, were examined, and the number of germinated spores was determined. The 
efficiency of each isolate at reducing germination relatively to the control was calculated.

Considering the results of the B. thuringiensis $\mathrm{B} 157$ experiment, a second experiment was performed to evaluate the urediniospore germination 12 hai using a scanning electron microscope. The leaf discs were transferred into a fixing solution $(25 \%$ glutaraldehyde in $0.1 \mathrm{M}$ sodium cacodylate buffer, $\mathrm{pH} 7.2$ ) at $5^{\circ} \mathrm{C}$. After $24 \mathrm{~h}$, the leaf discs were subjected to three successive 15 -min washes in $0.1 \mathrm{M}$ sodium cacodylate buffer $(\mathrm{pH} 7.2)$ and were dehydrated in a graded ethanol series $(30,50,70,80,90,95$ and twice in $100 \%$ ethanol) for $10 \mathrm{~min}$. The leaf discs were dried at the critical point inside a Balzers apparatus (model TEC-030) and were assembled, abaxial face up, onto aluminum tops for further gold coating inside a Balzers apparatus (model FDU-010). Using a scanning electron microscope, model LEO VP1430, the samples were visualized, the images were digitally recorded, and the antagonist distribution was recorded. In addition, the urediniospore germination in the leaves treated with $B$. thuringiensis $\mathrm{B} 157$ was compared to the control treatment.

\section{Dose-response ratio}

The extent of the rust reduction was examined following the application of different concentrations of antagonist at different times. Bacteria from each isolate were diluted in $0.85 \% \mathrm{NaCl}$ saline solution $+0.05 \%$ Tween 20 at seven different concentrations with the following $\mathrm{OD}_{540}$ readings measured using a spectrophotometer: 0 (no bacteria), 0.001, 0.01, 0.05, 0.1, 0.5, and 1.0. For each treatment, the bacteria were atomized onto the second and third pairs of leaves of the coffee plant seedlings. Immediately following the application of the bacterial treatments (time 0 ) or at 15 or 30 days after the application of the treatments, $H$. vastatrix inoculation was performed. At 40 days after the initial application, the severity of the rust on the leaves was evaluated, as described above. The efficiency of each treatment at reducing rust was calculated relative to the control treatments.

The experiment was performed twice using a completely randomized design, in a factorial scheme (7 concentrations $\times 3$ application times), and with three replications (one plant $=$ one experimental unit)

\section{Space-time separation between the antagonists and Hemileia vastatrix}

For each isolate, an experiment comprising the following seven treatments was performed: (i) application of the antagonist to the second pair of leaves and inoculation of $H$. vastatrix on the third pair of leaves; (ii) application of the antagonist to the third pair of leaves and inoculation of $H$. vastatrix on the second pair of leaves; (iii) application of the antagonist to the second and third pairs of leaves on one side of the plant and the inoculation of $H$. vastatrix on the same pairs of leaves on the other side of the plant; (iv) application of the antagonist in the soil $(30 \mathrm{~mL} /$ plant $)$ and the inoculation of $H$. vastatrix on the second and third pairs of leaves; (v) application of the antagonist and inoculation of $H$. vastatrix on the second and third pairs of leaves; (vi) the application of a copper hydroxide spray ( $2.2 \mathrm{~g}$ i.a./L) and inoculation of $H$. vastatrix on the second and third pairs of leaves; and (vii) application of 523 medium + saline solution and inoculation of $H$. vastatrix on the second and third pairs of leaves. To avoid contamination, the unapplied/ uninoculated leaves were coated with plastic film.

Hemileia vastatrix was inoculated 0 (immediately), $3,6,9$, or 12 days after the application of the antagonist. The plants were maintained in a dew chamber at $25^{\circ} \mathrm{C}$ in the dark. After $48 \mathrm{~h}$, the plants were transferred into a growth chamber maintained at $22^{\circ} \mathrm{C}$ with a 12 -h photoperiod. At 40 days after inoculation, rust severity was assessed, as previously described. The efficiency of each treatment at reducing rust severity was calculated relatively to treatment vii.

The experiment was performed twice using a completely randomized design, in a factorial scheme (7 treatments $\times 5$ application times), and with three replications (one plant $=$ one experimental unit).

\section{Data analysis}

Using Levene's test, it was observed homogeneity in the error variances for both runs of each experiment.. Therefore, the results of both runs were analyzed jointly using analysis of variance and means comparison by Tukey's test $(\alpha=0.05)$. For the dose-response ratio experiment, the data were $\log$ transformed before regression analysis to better fit the determination coefficients $\left(\mathrm{R}^{2}\right)$, error mean squares, parameter significance, normality and unbiased distribution of residuals. The statistical analyses were performed using SAS v. 9.1 software.

\section{RESULTS}

\section{Urediniospore germination in presence of bacterial cells and possible cell-produced metabolites}

The culture medium and saline solution did not affect urediniospore germination and rust severity (data not shown). The bacterial treatments reduced urediniospore germination, except by when the inactivated bacterial cells were used (Table 1). For B. thuringiensis B157, the supernatant and culture broth were more effective than the bacterial cells at reducing the germination; for $P$. putida P286, the germination was reduced equally by the three treatments (Table 1).

\section{Rust severity in presence of bacterial cells and possible antagonist-produced metabolites}

As previously mentioned, neither the control culture medium nor the saline solution affected germination and rust severity (data not shown). However, for both bacterial isolates, the supernatant, culture broth and bacterial cells significantly reduced the severity of the disease. The 
inactivated bacteria were not effective at reducing rust severity (Table 1).

\section{Urediniospore germination in coffee plant seedlings in presence of antagonistic bacteria}

Both bacterial isolates reduced the urenidiospore germination by $100 \%$. Electron microscopy demonstrated that the B157 isolate prevented the formation of germination tubes and inhibited the urediniospore germination (Figure $1)$.

\section{Dose-response ratio}

For both bacterial isolates, there was a significant correlation between the concentration and time of application. The efficiency of the antagonists increased with increased concentrations and decreased as the time of the application increased (for models A and B, $P<0.0001$ ) (Figure 2).

\section{Space-time separation between the antagonists and Hemileia vastatrix}

The bacterial isolates did not produce systemic protection. For the two bacterial isolates, a significant effect was detected only for the treatment factor $(\mathrm{P}<0.0001)$. The bacterial isolates were as efficient as copper hydroxide at reducing rust severity when they were applied at the inoculation site (Table 2).

\section{DISCUSSION}

Both inhibition of $H$. vastatrix urediniospore germination and reduction in rust severity were attributed to substance(s) exhibiting antifungal activity produced by the antagonistic bacteria. This hypothesis is based on the observation that the supernatant, which does not contain bacterial cells, was as efficient as the bacteriacontaining culture broth at reducing both germination and the disease. In the inactivated bacterial cells, the production of antifungal compounds ceased, and when these cells were used to treat the plants, no antagonistic effects were detected. Pseudomonas and Bacillus species produce different secondary metabolic products, including antibiotics and volatile organic antifungal and antiviral compounds (Raaijmakers et al., 2002; Ryan et al., 2008).

TABLE 1 - Efficiency (\%) of the treatments with Bacillus thuringiensis B157 and Pseudomonas putida P286 relatively to the control treatments (urediniospore suspension + saline solution or 523 medium as positive control, and urediniospore suspension + copper hydroxide as a negative control) in reducing both Hemileia vastatrix urediniospore germination and coffee leaf rust severity. Copper hydroxide reduced germination in $94.41 \%$ and severity in $98.66 \%$

\begin{tabular}{lcccc}
\hline \hline Treatment & \multicolumn{2}{c}{ Germination } & \multicolumn{2}{c}{ Severity } \\
\cline { 2 - 5 } & B157 & P286 & B157 & P286 \\
\hline Culture broth & $95.53 \mathrm{a}^{\mathrm{a}}$ & $76.53 \mathrm{a}$ & $99.71 \mathrm{a}$ & $98.25 \mathrm{a}$ \\
Supernatant & $93.02 \mathrm{a}$ & $73.74 \mathrm{a}$ & $99.24 \mathrm{a}$ & $95.29 \mathrm{a}$ \\
Bacterial cells & $78.61 \mathrm{~b}$ & $76.11 \mathrm{a}$ & $94.65 \mathrm{a}$ & $95.03 \mathrm{a}$ \\
Inactivated bacterial cells & $0.83 \mathrm{c}$ & $0.00 \mathrm{~b}$ & $0.00 \mathrm{~b}$ & $6.18 \mathrm{~b}$ \\
\hline
\end{tabular}

an each column, the means followed by the same letter do not differ (Tukey's test, $\alpha=0.05$ ).

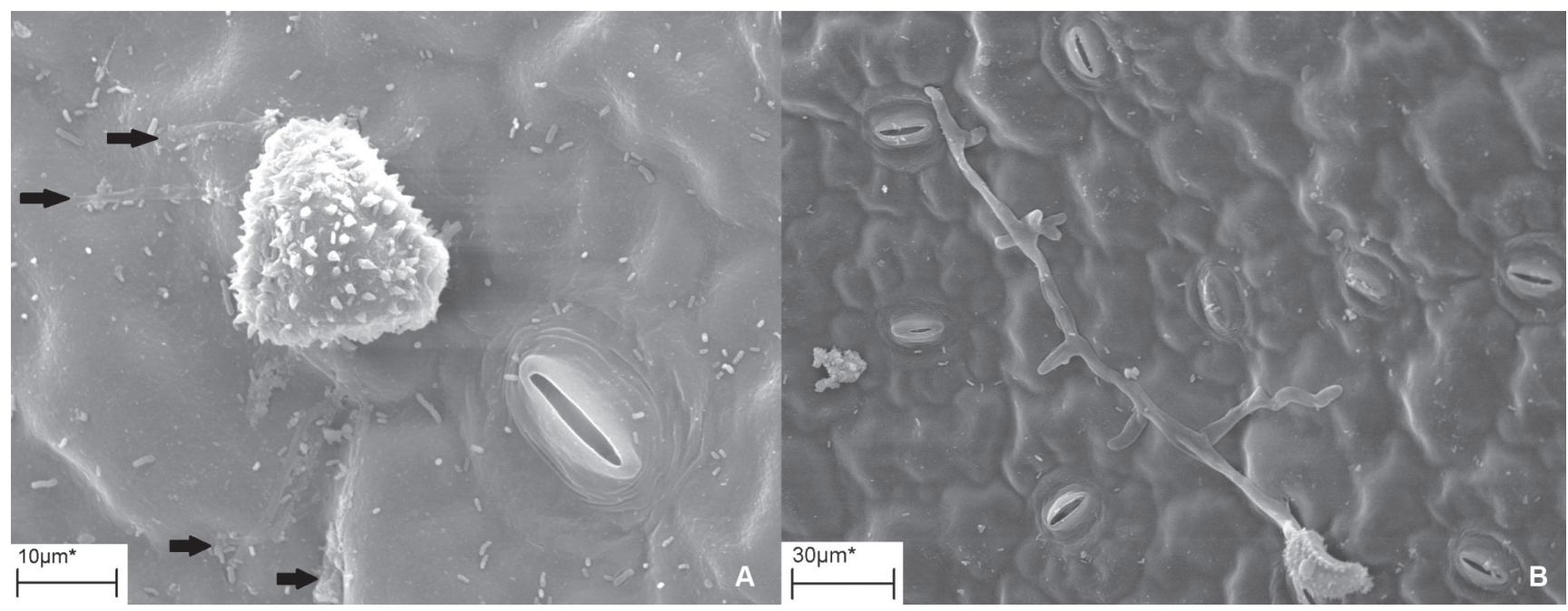

FIGURE 1 - A. Inhibition of Hemileia vastatrix urediniospore germination in presence of bacterial cells and possible metabolites produced by $B$. thuringiensis. Arrows indicate concentration of bacterial cells close to H. vastatrix germination tubes; B. Urediniospore germination in absence of the antagonist. 

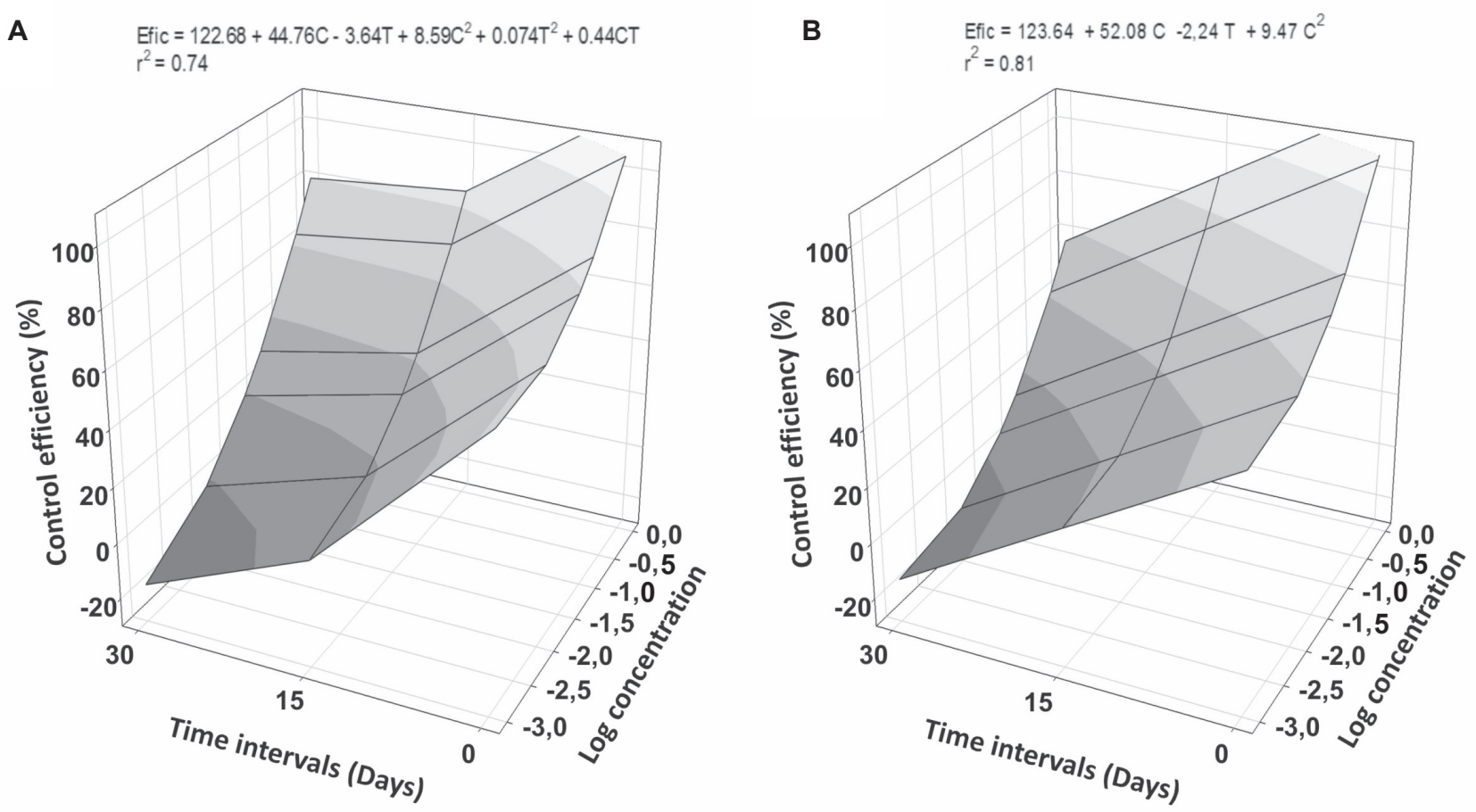

FIGURE 2 - Control efficiency (Efic) of coffee plant rust in combinations of bacterial cells concentration (C) and time intervals (T) between cell application and Hemileia vastatrix inoculation. A. Bacillus thuringiensis B157; B. Pseudomonas putida P286. Intercepts and slopes of both models differed significantly from zero $(P<0.05)$.

TABLE 2 - Efficiency (\%) of the treatments with Bacillus thuringiensis B157 and Pseudomonas putida P286 relatively to the control (application of copper hydroxide spray or 523 medium + saline solution and inoculation of Hemileia vastatrix (Hv) on the second and third pair of leaves), in reducing coffee leaf rust severity, with and without space split between the application of the bacteria and Hv inoculation. Copper hydroxide reduced severity in $98.88 \%$

\begin{tabular}{lcc}
\hline \hline Treatment & B157 & P286 \\
\hline Isolates and Hv at the $2^{\text {nd }}$ and $3^{\text {rd }}$ pair of leaves at the same site & $99.16 \mathrm{a}^{\mathrm{a}}$ & $99.35 \mathrm{a}$ \\
Isolates at the $3^{\text {rd }}$ pair and Hv at the $2^{\text {nd }}$ & $3.75 \mathrm{~b}$ & $3.70 \mathrm{~b}$ \\
Isolates onto the soil and Hv at the $2^{\text {nd }}$ and $3^{\text {rd }}$ pairs & $0.86 \mathrm{~b}$ & $2.30 \mathrm{~b}$ \\
Isolates at the $2^{\text {nd }}$ pair and Hv at the $3^{\text {rd }}$ one & $-6.79 \mathrm{~b}$ & $-4.62 \mathrm{~b}$ \\
Isolates on the right side of the plant and Hv on the left, & $-19.64 \mathrm{~b}$ & $-5.01 \mathrm{~b}$ \\
both at the $2^{\text {nd }}$ and $3^{\text {rd }}$ pairs & \\
\hline
\end{tabular}

an each column, the means followed by the same letter do not differ (Tukey's test, $\alpha=0.05$ ).

The broad-spectrum antibiotic 2,4diacetylphloroglucinol, produced by Pseudomonas $s p$., is known to be a natural suppressor in soil and has a direct effect on pathogens (Raaijmakers et al., 1999; Weller et al., 2012). This compound, produced by P. fluorescens, induced resistance to Peronospora parasitica and Pseudomonas syringae pv. tomato in Arabidopsis thaliana plants (Lavicoli et al., 2003; Weller et al., 2012). Pseudomonas species are reported as siderophore producers, e.g. pyoverdin, which are organic compounds of low molecular weight and which sequester iron, especially in environments with limited availability of the element (Neilands et. al., 1986; Flaishman et. al., 1996). However, it is known that the spores of most biotrofic pathogens do not require any exogenous substance to germinate. Hemileia vastatrix, pathogen studied in this paper, is biotrophic and therefore it depends on the living host cells for its nutrition, growth and multiplication. During the pathogen infective process it occurs sequentially urediniospore deposition on the leaf abaxial face, germination and posteriorly appressoria formation on the plant stomata (Coutinho et al., 1993; Martins \& Moraes, 1996; Silva et al., 1999, 2002). The only requirements reported yet in order to occur urediniospores germination are free water and a leaf topography that directs the germ tube tip to an stomata opening (Mendgen \& Voegele, 2005). In the case 
described in this paper, the pathogen's inhibition occured at the spore germination stage. There is no report of needs of iron or any other nutrient to $H$. vastatrix infective process, the formation of the pre-penetration structure of the pathogen is only associated with free water and leaf topography (Azinheira et al., 2001; Azinheira, 2005). Based on this fact, the compound with antifungal activity produced by P286 isolate was not considered as being siderophore.

There are reports that coffee plant endophytic species, Escherichia fergusonii and Acinetobacter calcoaceticus, produce siderophores (Silva et al., 2012). In this case the authors reported that these species had an effect on the coffee growth promotion and had not a direct effect on the pathogen or on the reduction of the disease severity. Eichhorn et al. (2006) reported the importance of iron capture during the biotrophic development of Ustilago maydis hyphae. However, this fact is related to the pathogen development only after the spore germination and host penetration, being associated with the fungus ability to colonize Zea mays tissues. In other pathosystems, there is a relationship between the dimensions of the outside edges of the guard cells and chemicals when forming the appressoria (Collins et al., 2001; Wiethölter et al. 2003). Despite these facts, it is necessary to evaluate if the P286 isolate can produce siderophore, like pyoverdin, and if it could influence urediniospore germination.

For B. subtilis, the antagonism of Gloeosporium gloeoesporioides was attributed to the antibiotic itaurine (Cho et al., 2003). Surfactin, produced by B. licheniformis, has a direct effect on spore germination and mycelial growth in Magnaporthe grisea (Tendulkar et al., 2007). This compound, when produced by B. subtilis, induced resistance to Botrytis cinerea in bean plants (Ongena et al., 2007). Therefore, we propose that the observed antagonism was caused by direct compound (s) production.

The disease control efficiency increased when highest concentrations of both bacterial isolates were used. Therefore, it is likely that there is a direct relationship between the efficiency of the pathogen control and the concentration of the antifungal compound. The compound was degraded over time because the pathogen control efficiency also decreased with time, mainly at the lower concentrations of the bacterial isolates. Under field conditions, the bacterial isolates produced a significant reduction in the incidence and severity of rust when applied at an $\mathrm{OD}_{540}$ of 0.2 (Haddad et al., 2009). At this concentration in greenhouse, the bacteria were not as effective as in field experiments. This difference is likely related to the $H$. vastatrix inoculum; under greenhouse conditions, spore germination is usually higher than in the field (data not shown). Furthermore, in the greenhouse, the inoculation occurs just once at a high inoculum concentration, whereas in the field, the inoculum is gradually deposited over time and at lower concentrations. Therefore, both the effective concentration and the application time must be determined for field conditions.

Systematicity is an essential criterion for ISR determination. For both bacterial isolates, only a local effect was observed. Furthermore, when resistance is induced by an antagonist applied at a separate location from the pathogen, it is expected that the time interval between the inducer application and the expression of resistance will be longer than when the antagonist is applied at the inoculation site. For example, when Lysobacter enzymogenes was applied at the inoculation site of the Bipolaris sorokiniana, the resistance response in tall fescue (Festuca arundinacea) was immediate, whereas with the spatial separation of the treatment and inoculation sites, the effect was delayed for two days (Kilic-Ekici \& Yuen, 2003). The efficiency of both bacterial isolates to control the disease increased when the time of the application was reduced.

In this study, the findings do not follow the criteria set by Steiner \& Schömbeck (1995) to account for the ISR. In addition, we determined that the bacterial isolates did not protect the coffee plants from C. coffeicola infections (data not shown). Although both bacterial isolates should be challenged with other pathogens to expand the scope of the protection test, in this study, when systemic resistance was induced, the protection spectrum observed was not as wide as expected. Therefore, the data reinforce that the main mechanism of antagonism of B. thuringiensis $\mathrm{B} 157$ and P. putida P286 is mediated by the production of toxic compounds to the germination of $H$. vastatrix urediniospores.

Organic coffee production is increasing in Brazil. Although the use of a number of copper compounds to protect plants against rust is allowed, the biocontrol of diseases has a promising future in the Brazilian coffee industry. The use of bacteria that produce compounds that inhibit spore germination is an efficient strategy for rust biocontrol in coffee plants. The Bacillus species reduced the urediniospore germination by greater than $40 \%$ and caused deformation of the germination tubes (Shiomi et al., 2006). It is believed that the efficiency of the biocontrol agent is directly linked to the interference on the initial establishment of the disease stages (Yoshida et al., 2001; Guetsky et al., 2001). Therefore, substance(s) with antifungal action produced by the antagonist bacteria was/were responsible to disease control, and there was a direct effect between the antagonist concentrations and the disease control. The use of B. thuringiensis $\mathrm{B} 157$ and/or P. putida $\mathrm{P} 286$, or the compound(s) they excrete, in the field is likely to become a reality in Brazil, particularly for organic coffee production. An important next step will be to identify and characterize the toxic compound(s) with potential to be a new chemical fungicide compound.

\section{ACKNOWLEDGEMENTS}

We are grateful to the Conselho Nacional de Desenvolvimento Científico e Tecnológico - CNPq and the 
Fundação de Amparo à Pesquisa do Estado de Minas Gerais - FAPEMIG for sponsoring this project.

\section{REFERENCES}

Azinheira HG (2005) Estudos celulares bioquímicos e moleculares da diferenciação de Hemileia vastatrix. PhD Thesis, Universidade Técnica de Lisboa. Lisboa Portugal.

Azinheira HG, Silva MC, Guerra-Guimarães L, Mendgen K, Rodrigues Jr CJ, Ricardo CP (2001) Development of infection structures of Hemileia vastatrix on artificial membranes. In: Proceedings of the 11th Congress of the Mediterranean Phytopathological Union and 3rd Congress of the Sociedade Portuguesa de Fitopatologia. Évora Portugal. Sociedade Portuguesa de Fitopatologia. pp. 353-355.

Caixeta GZT, Pedini S (2002) Comercialização de café orgânico. Informe Agropecuário 23:149-152.

Carvalho VL, Cunha RL, Chalfoun SM (2002) Manejo ecológico das principais doenças do café. Informe Agropecuário 23:101114.

Cho SJ, Lee SK, Cha BJ, Kim YH, Shin, KS (2003) Detection and characterization of the Gloeosporium gloeosporioides growth inhibitory compound iturin a from Bacillus subtilis strain KS03. FEMS Microbiology Letters 223:47-51.

Collins TJ, Moerschbacher BM, Read ND (2001) Synergistic induction of wheat stem rust appressoria by chemical and topographical signals. Physiological and Molecular Plant Pathology 58:259-266.

Costa MJN, Zambolim L, Rodrigues FA (2007) Avaliação de produtos alternativos no controle da ferrugem do cafeeiro. Fitopatologia Brasileira 32:150-155.

Coutinho T, Rijkenberg FHJ, Van Asch MAJ (1993) Development of infection structures by Hemileia vastatrix in resistant and susceptible selections of Coffea and in Phaseolus vulgaris. Canadian Journal of Botany 71:1001-1008.

Cristancho AMA (1995) Efecto protector de la bacteria Bacillus thuringiensis en plantas de café contra el desarrollo de Hemileia vastatrix Berk. et Br. Cenicafé 46:140-151.

Cui X, Harling R (2006) Evaluation of bacterial antagonists for biological control of broccoli head rot caused by Pseudomonas fluorescens. Phytopathology 96:408-416.

De La Fuente L, Landa BB, Weller DM (2006) Host crop affects rhizosphere colonization and competitiveness of 2,4diacetylphloroglucinol-producing Pseudomonas fuorescens. Phytopathology 96:751-762.

Duffy BK, Défago G (1999) Environmental factors modulating antibiotic and siderophore biosynthesis by Pseudomonas fluorescens biocontrol strains. Applied and Environmental Microbiology 65:2429-2438.

Eichhorn H, Lessing F, Winterberg B, Schirawski J, Kämper J, Müller P, Kahmann R (2006) A ferroxidation/permeation iron uptake system is required for virulence in Ustilago maydis. Plant Cell 18:3332-3345.

Flaishman MA, Eyal Z, Zilberstein A, Voisard C, Haas D (1996) Suppression of Septoria tritici blotch and leaf rust of wheat by recombinant cyanide-producing strains of Pseudomonas putida.
Molecular Plant-Microbe Interactions 9:642-645.

Guetsky R, Shtienberg D, Elad Y, Dinoor A (2001) Combining biocontrol agents to reduce the variability of biological control. Phytopathology 91:621-627.

Gouveia MMC, Ribeiro A, Várzea VMP, Rodrigues JCJ (2005) Genetic diversity in Hemileia vastatrix based on RAPD markers. Mycologia 97:396-404.

Haddad F, Maffia LA, Mizubuti ESG, Romeiro RS (2004) Biocontrol of coffee leaf rust with antagonists isolated from organic crops. Phytopathology 94:S37.

Haddad F, Maffia LA, Mizubuti ESG, Teixeira H (2009) Biological control of coffee rust by antagonistic bacteria under field conditions in Brazil. Biological Control 49:114-119.

Han SH, Lee SJ, Moon JH, Park KH, Yang KY, Cho BH, Kim KY, Kim YW, Lee MC, Anderson AJ, Kim YC (2006) GacS-dependent production of 2R, 3R-butanediol by Pseudomonas chlororaphis O6 is a major determinant for eliciting systemic resistance against Erwinia carotovora but not against Pseudomonas syringae pv. tabaci in tobacco. Molecular Plant-Microbe Interactions 19:924930.

Harman E (2000) Myths and dogmas of biocontrol: Changes in perceptions derived from research on Trichoderma harzianum T-22. Plant Disease 84:377-393.

Kado CI, Heskett MG (1970) Selective media for isolation of Agrobacterium, Corynebacterium, Erwinia, Pseudomonas, and Xantohomonas. Phytopathology 60:965-975.

Kilic-Ekici O, Yuen GY (2003) Induced resistance as a mechanism of biological control by Lysobacter enzymogenes strain C3. Phytopathology 93:1103-1110.

Lanna Filho R, Ferro HM, Pinho RSC (2010) Controle biológico mediado por Bacillus subtilis. Revista Trópica 4:12-20.

Lavicoli A, Boutet E, Buchala A, Métraux JP (2003) Induced systemic resistance in Arabidopsis thaliana in response to root inoculation with Pseudomonas fluorescens CHA0. Molecular Plant-Microbe Interactions 16: 851-858.

MAPA(2013) Ministério da Agricultura, Pecuária e Abastecimento. Available at: www.agricultura.gov.br. Acessed on 10/01/2013.

Martins EMF, Moraes WBC (1996) Development of Hemileia vastatrix in coffee plants with genetic and induced resistance. Journal of Phytopathology 144:519-526.

Neilands JB, Leong SA (1986) Siderophores in relation to plant growth and disease. Annual Review of Plant Physiology 37:187208.

Melnick RL, Zidack NK, Bailey BA, Maximova SN, Guiltinan M, Backman PA (2008) Bacterial endophytes: Bacillus spp. from annual crops as potential biological control agents of black pod rot of cacao. Biological Control 46:46-56.

Mendgen K, Voegele RT (2005) Biology of rusts and mechanisms of infection. In: Zambolim L, Zambolim EM, Várzea VMP (Eds.) Durable Resistance to Coffee Leaf Rust. Viçosa MG, Brazil. Suprema Gráfica e Editora. pp. 233-248.

Ongena M, Jourdan E, Adam A, Paquot M, Brans A, Joris B, Arpigny JL, Thonart P (2007) Surfactin and fengycin lipopeptides of Bacillus subtilis as elicitors of induced systemic resistance in plants. Environmental Microbiology 9:1084-1090. 
Porras NC, Leguizamon CJE, Martinez MM (1999) Induccion de resistencia por Pseudomonas spp., em plantulas de cafe contra la roya del cafeto Hemileia vastatrix Berk. et Br. Ascolfi-Informa 25:12-14.

Raaijmakers JM, Bonsall RF, Weller DM (1999) Effect of population density of Pseudomonas fluorescens on production of 2,4-diacetylphloroglucinol in the rhizosphere of wheat. Phytopathology 89:470-475.

Raaijmakers JM, Vlami M, Souza JT (2002) Antibiotic production by bacterial biocontrol agents. Antonie van Leeuwenhoek 81:537547.

Ryan RP, Germaine K, Franks A, Ryan DJ, Dowling DN (2008) Bacterial endophytes: Recent developments and applications. FEMS Microbiology Letters 278:1-9.

Romeiro RS, Lanna Filho R, Vieira Junior JR, Silva HSA, BaracatPereira MC, Carvalho MG (2005) Macromolecules released by a plant growth-promoting rhizobacterium as elicitors of systemic resistance in tomato to bacterial and fungal Pathogens. Journal of Phytopathology 153:120-123.

Saravanan T, Bhaskaran R, Muthusamy M (2004) Pseudomonas fluorescens induced enzymological changes in banana roots $(\mathrm{Cv}$. Rasthali) against Fusarium wilt disease. Plant Pathology Journal 3:72-80.

Shiomi HF, Silva HSA, Melo IS, Nunes FV, Bettiol W (2006) Bioprospecting endophytic bacteria for biological control of coffee leaf rust. Scientia Agricola 63:32-39.

Silva HSA, Tozzi JPL, Terrasan CRF, Bettiol W (2012) Endophytic microorganisms from coffee tissues as plant growth promoters and biocontrol agents of coffee leaf rust. Biological Control 63:62-67.

Silva MC, Nicole M, Guerra-Guimarães L, Rodrigues Jr CJ (2002) Hypersensitive cell death and post-haustorial defense responses arrest the orange rust (Hemileia vastatrix) growth in resistant coffee leaves. Physiological and Molecular Plant Pathology 60:169-183.

Silva MC, Nicole M, Rijo L, Geiger JP, Rodrigues Jr CJ (1999) Cytochemical aspects of the plant-rust fungus interface during the compatible interaction Coffea arabica (cv. Caturra)-Hemileia vastatrix (race III). International Journal of Plant Sciences 160:7991.

Steiner U, Schömbeck F (1995) Induced disease resistence in monocots. In: Hammerschmit R, Kuc J (Eds.) Induced Resistance to Disease in Plants (Developments in Plant Pathology, Vol. 4). Dordrecht The Netherlands. Kluwer Academic Publishers. pp. 86110.

Tendulkar SR, Saikumari YK, Patel V, Raghotama S, Munshi TK, Balaram P, Chattoo BB (2007) Isolation, purification and characterization of an antifungal molecule produced by Bacillus licheniformis BC98, and its effect on phytopathogen Magnaporthe grisea. Journal of Applied Microbiology 103:2331-2339.

Upadhyay A, Srivastava S (2009) Evaluation of multiple plant growth promoting traits of an isolate of Pseudomonas fluorescens strain Psd. Indian Journal of Experimental Biology 48:601-609.

Yoshida S, Hiradate S, Tsukamoto T, Hatakeda K, Shirata A (2001) Antimicrobial activity of culture filtrate of Bacillus amyloliquefaciens RC-2 isolated from mulberry leaves. Phytopathology 91:181-187.

Vale FXR, Fernandes Filho EI, Liberato JR (2003) Quant: A software for plant disease severity assessment. Proceedings of the $8^{\text {th }}$ International Congress of Plant Pathology. Christchurch New Zealand. International Society for Plant Pathology. p. 105.

Van der Vossen HAM (2005) State-of-the-art of developing durable resistance to biotrophic pathogens in crop plans, such as coffee leaf rust. In: Zambolim L, Zambolim EM, Várzea VMP (Eds.) Durable Resistance to Coffee Leaf Rust. Viçosa MG, Brazil. Suprema Gráfica e Editora. pp. 1-29.

Weller DM, Mavrodi DV, van Pelt JA, Pieterse CMJ, van Loon LC, Bakker PAHM (2012) Induced systemic resistance in Arabidopsis thaliana against Pseudomonas syringae pv. tomato by 2,4-diacetylphloroglucinol-producing Pseudomonas fluorescens. Phytopathology 102:403-412.

Wiethölter N, Horn S, Reisige K, Beike U, Moerschbacher B (2003) In vitro differentiation of haustorial mother cells of the wheat stem rust fungus, Puccinia graminis f. sp. tritici, triggered by the synergistic action of chemical and physical signals. Fungal Genetics and Biology 38:320-326.

$\overline{\text { TPP 2013-0032 - Received } 27 \text { February } 2013 \text { - Accepted } 19 \text { June } 2013}$

Section Editor: Bernardo A. Halfeld-Vieira 